\title{
Konferencja "Znaczenie ustawodawstwa Justyniana w kształtowaniu europejskiej kultury prawnej. Refleksje w 1450. rocznicę śmierci cesarza" Białystok 21-22 maja 2015 r.
}

W dniach 21-22 maja 2015 r. odbyła się w Białymstoku konferencja pt. „Znaczenie ustawodawstwa Justyniana w kształtowaniu europejskiej kultury prawnej. Refleksje w 1450. rocznicę śmierci cesarza". Jej organizatorem był Zakład Łacińskiej Kultury Prawnej Katedry Nauk Historyczno-Prawnych i Komparatystyki Prawniczej Wydziału Prawa Uniwersytetu w Białymstoku.

Celem konferencji było przybliżenie działalności cesarza Justyniana I Wielkiego na polu ustawodawczym i ukazanie wpływu, jaki wywarły przeprowadzone przez niego reformy na kształtowanie się kultury prawnej Europy.

W budynku białostockiego Wydziału Prawa zgromadzili się przedstawiciele kilku ośrodków akademickich, którzy przedstawili wyniki swoich badań dotyczące przedmiotowej problematyki. Uroczystego otwarcia konferencji i powitania uczestników dokonał ks. dr hab. Florian Lempa, prof. Uniwersytetu w Białymstoku, kierownik Zakładu Łacińskiej Kultury Prawnej. Pierwszy dzień obrad rozpoczął swoim wystąpieniem prof. dr hab. Bronisław Sitek (Szkoła Wyższa Psychologii Społecznej w Warszawie), Omnem legum tramitem, ... ita esse confusum, ut in infinitum extendatur et nullius humanae naturae capacitate concludatur. Analizował w nim ogłoszoną przez Justyniana 15 grudnia 530 r. konstytucję Deo auctore, która dała początek pracom nad ułożeniem Digestów. Następnie uczestnicy mieli okazję wysłuchać referatów gości przybyłych z Università degli Studi di Bari Aldo Moro we Włoszech, dotyczacych takich zagadnień, jak: prof. Maria Luisa De Filippi, Analogie e differenze tra il Digesto giustinianeo ed i Fragmenta Vaticana; prof. Michele Indellicato, La dimensioni etiche del Codice di Giustiniano; prof. Ferdinando Parente, La persona come homo: evoluzione e tutele. Kolejne prelekcje wygłosili ks. dr Piotr Sadowski (Uniwersytet Opolski), Status prawny osób niestyszacych i niemówiących w Corpus Iuris Civilis Justyniana i dr Sławomir Kursa (Szkoła Wyższa Psychologii Społecznej w Warszawie), Znaczenie reform Justynian dla prawa spadkowego.

Drugi dzień obrad rozpoczął mgr Stefan Karolak (Europejska Wyższa Szkoła Prawa i Administracji) odczytem Justynian I Wielki i poszukiwanie zagubionej sprawiedliwości. Po nim głos zabierali kolejni prelegenci, których referaty koncentrowały się wokół następujacych kwestii: dr Aleksandra Szymańska (Uniwersytet Wrocławski), O średniowiecznym podziale Digestów; dr Ireneusz Jakubowski (Uniwersytet Łódzki); Cesarz Justynian, człowiek i prawodawca w opinii Tadeusza Czackiego; ks. dr 
hab. Florian Lempa (prof. Uniwersytetu w Białymstoku), Recepcja prawa justyniańskiego o przedawnieniu w Kodeksie Prawa Kanonicznego i Kodeksie Kanonów Kościołów Wschodnich; dr Andrzej Chmiel (Uniwersytet Marii Curie-Skłodowskiej), Zasada crimen extinguitur mortalitate w prawie rzymskim; dr Przemysław Kubiak (Uniwersytet Łódzki), "Czynny żal” w świetle konstytucji cesarskich; dr Krzysztof Szczygielski (Uniwersytet w Białymstoku), Prawo rzymskie w pracach Komisji Kodyfikacyjnej Rzeczypospolitej Polskiej przygotowującej Kodeks zobowiazań. Dodać trzeba, iż w programie konferencji przewidziane było także wystąpienie mgr Iwony Krzemińskiej z Uniwersytetu Warszawskiego, Prawo finansowe i polityka finansowa w czasach cesarza Justyniana, która jednak z przyczyn losowych nie mogła dotrzeć do Białegostoku.

Prezentowane wystąpienia spotkały się z dużym zainteresowaniem uczestników, czego dowodem była żywa dyskusja toczona po zakończeniu poszczególnych sesji. Odnotować też należy, iż konferencji towarzyszyła wystawa poświęcona osobie bizantyjskiego cesarza, którą tworzyły następujące działy tematyczne: Justynian i jego prawodawstwo w dziełach sławnych Polaków; Justynian i jego prawodawstwo w malarstwie, komiksie $i$ kaligrafii; Justynian $i$ jego prawodawstwo $w$ filatelistyce, filokartystyce i fonotelistyce. 